\title{
Army Aviation Operations in the Pacific Theater
}

A Monograph

by

MAJ Kevin P. Kane

United States Army

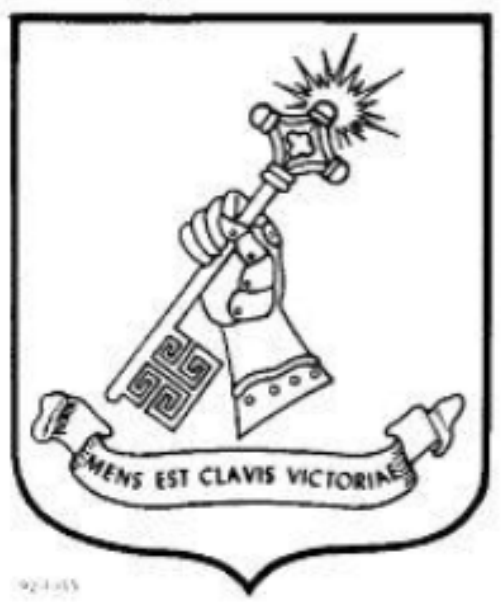

School of Advanced Military Studies

United States Army Command and General Staff College

Fort Leavenworth, Kansas

\section{4-02}

Approved for public release; distribution is unlimited 


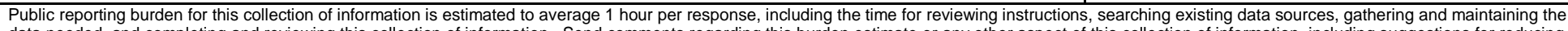

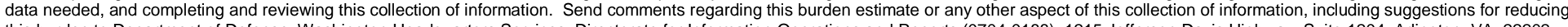

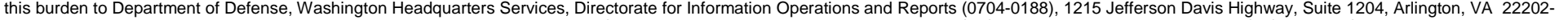

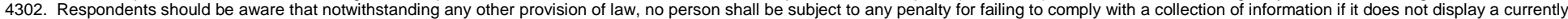
valid OMB control number. PLEASE DO NOT RETURN YOUR FORM TO THE ABOVE ADDRESS.

\begin{tabular}{l|l|l} 
1. REPORT DATE (DD-MM-YYYY) & 2. REPORT TYPE & 3. DATES COVERED (FrOm - TO)
\end{tabular}

04-12-2014 SAMS Monograph

Jan 14 - Dec 14

4. TITLE AND SUBTITLE

Army Aviation Operations in the Pacific Theater

5a. CONTRACT NUMBER

5b. GRANT NUMBER

5c. PROGRAM ELEMENT NUMBER

6. AUTHOR(S)

Major Kevin P. Kane

5d. PROJECT NUMBER

5e. TASK NUMBER

5f. WORK UNIT NUMBER

7. PERFORMING ORGANIZATION NAME(S) AND ADDRESS(ES)

School of Advanced Military Studies (SAMS)

8. PERFORMING ORGANIZATION REPORT

201 Reynolds Avenue

Fort Leavenworth, KS 66027-2134 NUMBER

9. SPONSORING I MONITORING AGENCY NAME(S) AND ADDRESS(ES)

Command and General Staff College

731 McClellan Avenue

Fort Leavenworth, KS 66027-1350

10. SPONSOR/MONITOR'S ACRONYM(S)

CGSC

11. SPONSOR/MONITOR'S REPORT NUMBER(S)

12. DISTRIBUTION / AVAILABILITY STATEMENT

Approved for Public Release; Distribution Unlimited

\section{SUPPLEMENTARY NOTES}

\section{ABSTRACT}

Army aviation offers a very real capability for shipboard employment. Under the right circumstances, such a capability can be invaluable to a Joint Force commander. This monograph explores potential employment options and force packages for Army aviation operating from Navy vessels and platforms. It assesses the operational utility of such employment and considers a number of implications and impacts associated with shipboard operations. Through the use of ship-based force packages that can be scaled from team to battalion task force size and tailored with specific capabilities, Army aviation can provide support to a wide range of joint force missions.

\section{SUBJECT TERMS}

Army aviation, Shipboard operations, Pacific theater

\begin{tabular}{l|l|l|l|l|}
\hline 16. SECURITY CLASSIFICATION OF: & $\begin{array}{l}\text { 17. LIMITATION } \\
\text { OF ABSTRACT }\end{array}$ & $\begin{array}{l}\text { 18. NUMBER } \\
\text { OF PAGES }\end{array}$ & 19a. NAME OF RESPONSIBLE PERSON \\
\cline { 1 - 2 } \begin{tabular}{l|l} 
a. REPORT \\
Unclassified
\end{tabular} & $\begin{array}{l}\text { b. ABSTRACT } \\
\text { Unclassified }\end{array}$ & $\begin{array}{l}\text { c. THIS PAGE } \\
\text { Unclassified }\end{array}$ & & $\begin{array}{l}\text { 19b. TELEPHONE NUMBER (include area } \\
\text { code) } \\
913-758-3302\end{array}$ \\
\end{tabular}




\section{Monograph Approval Page}

Name of Candidate: MAJ Kevin P. Kane

Monograph Title: $\quad$ Army Aviation Operations in the Pacific Theater

Approved by:

Peter J. Schifferle, PhD

Monograph Director

Andrew Morgado, COL
Henry A. Arnold III, COL
, Director, School of Advanced Military Studies

Accepted this 23rd day of November 2014 by:

Robert F. Baumann, PhD

, Director, Graduate Degree Programs

The opinions and conclusions expressed herein are those of the student author and do not necessarily represent the views of the US Army Command and General Staff College or any other governmental agency. (References to this study should include the foregoing statement.) 


\begin{abstract}
Army Aviation Operations in the Pacific Theater, by MAJ Kevin P. Kane, 46 pages.

Army aviation offers a very real capability for shipboard employment. Under the right circumstances, such a capability can be invaluable to a Joint Force commander. This monograph explores potential employment options and force packages for Army aviation operating from Navy vessels and platforms. It assesses the operational utility of such employment and considers a number of implications and impacts associated with shipboard operations. Based on the developing requirement for ship-based employment of Army aviation assets, this monograph seeks to determine what should the operational role be for Army aviation in a maritime theater, specifically the United States Pacific Command's area of responsibility? Through the use of shipbased force packages that can be scaled from team to battalion task force size and tailored with specific capabilities (attack, reconnaissance, security, air assault, air movement, and medical evacuation), Army aviation can provide support to a wide range of joint force missions.
\end{abstract}




\section{Contents}

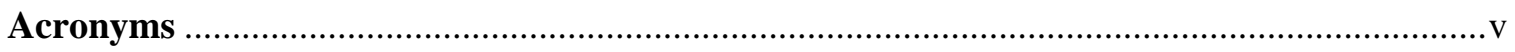

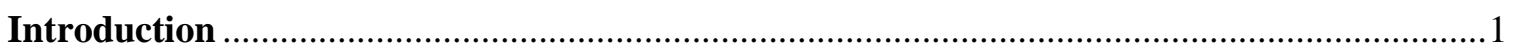

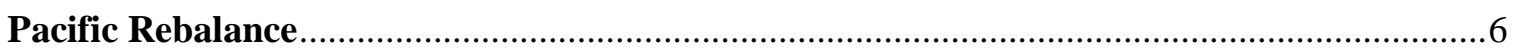

Army Shipboard Operations Historical Case Studies........................................................10

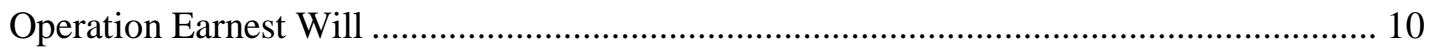

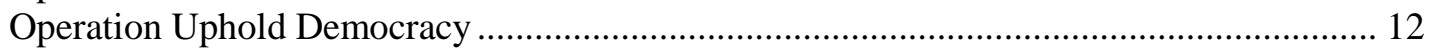

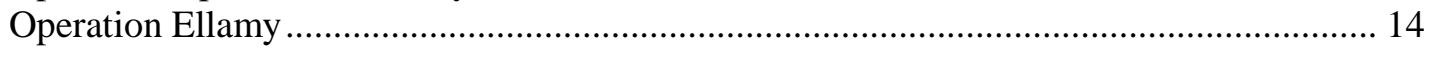

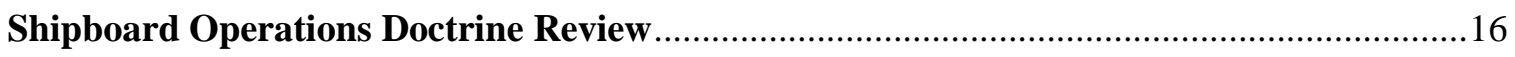

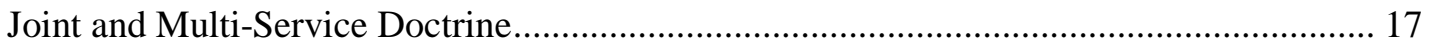

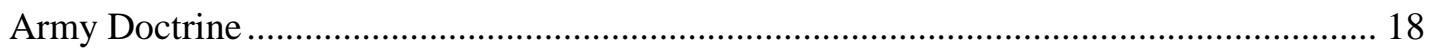

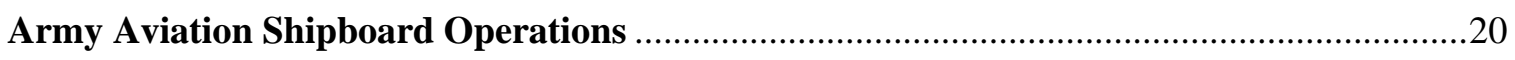

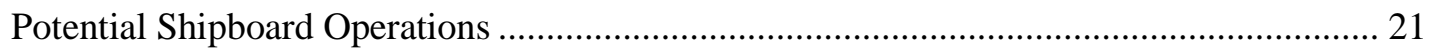

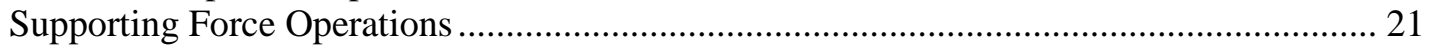

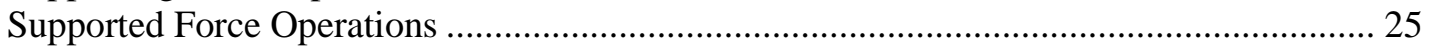

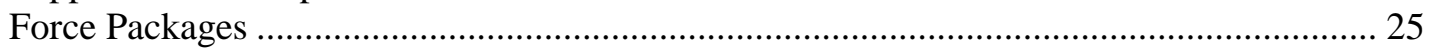

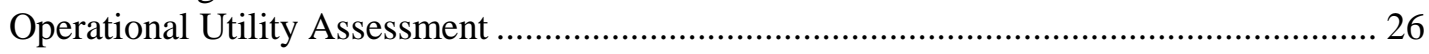

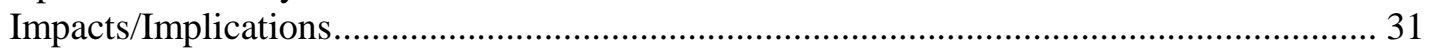

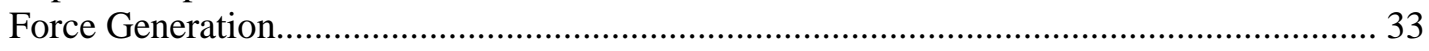

Army Aviation Shipboard Operations: A Scenario ...................................................... 34

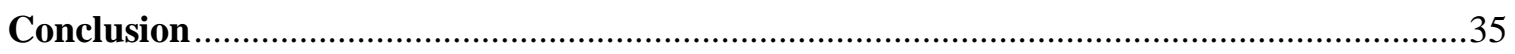

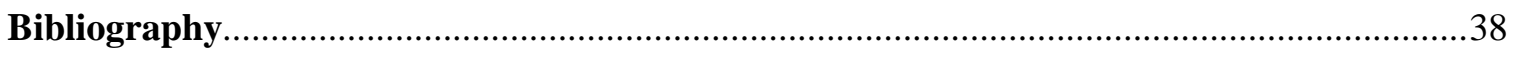




\section{Acronyms}

\begin{tabular}{|c|c|}
\hline ALSE & Aviation Life Support Equipment \\
\hline AOR & Area of Responsibility \\
\hline ASE & Aviation Survivability Equipment \\
\hline AWT & Attack Weapons Team \\
\hline CENTCOM & Central Command \\
\hline EMI & Electro-Magnetic Interference \\
\hline FM & Field Manual \\
\hline JOAC & Joint Operational Access Concept \\
\hline JTF & Joint Task Force \\
\hline JP & Joint Publication \\
\hline LCS & Littoral Combat Ship \\
\hline LHD & Landing Helicopter Dock \\
\hline LPD & Landing Platform Dock \\
\hline MEDEVAC & Medical Evacuation \\
\hline MEU & Marine Expeditionary Unit \\
\hline MTOE & Modified Table of Organization and Equipment \\
\hline MUM-T & Manned-Unmanned Teaming \\
\hline NATO & North Atlantic Treaty Organization \\
\hline PR & Personnel Recovery \\
\hline SCAR & Strike Coordination and Reconnaissance \\
\hline TF & Task Force \\
\hline TTP & Tactics Techniques and Procedures \\
\hline UAS & Unmanned Aerial System \\
\hline UK & United Kingdom \\
\hline
\end{tabular}


US United States

USAACE United States Army Aviation Center of Excellence

USARPAC United States Army Pacific

USMC United States Marine Corps

USN United States Navy

USPACOM United States Pacific Command

VERTREP Vertical Replenishment

VOD Vertical Onboard Delivery 


\section{Introduction}

Since men live upon the land and not upon the sea, great issues between nations at war have always been decided - except in the rarest cases - either by what your army can do against your enemy's territory and national life or else by the fear of what the fleet makes it possible for your army to do.

- Sir Julian Stafford Corbett, Some Principles of Maritime Strategy

Throughout history, from before the Peloponnesian Wars to today, nations have employed maritime and land forces in a mutually supporting manner to ensure continued access to the global commons and, in more modern times, ensure the free flow of goods and commerce. Global commons, areas outside the jurisdiction of any nation, are of enduring interest to the United States (US) because they are the conduits for global commerce and vital to the projection of military power. Adversaries have continually challenged America’s access to the global commons and the US military has defended these threats through military action that often involved land forces. As referenced in the above epigraph, the maritime strategist Sir Julian Corbett describes the overall importance of land forces in determining the ultimate outcome of a conflict. As the US and other powers of the world begin to focus their priorities and efforts to the Asia-Pacific region, it is wise to remember the words of Corbett. Too large an emphasis on the maritime and air domains of the Asia-Pacific region, while ignoring the land domain, could lead to the inability to achieve long-term strategic stability and success.

In recent strategic documents, including the 2010 National Security Strategy and the 2012 Sustaining US Global Leadership: Priorities for the 21st Century Defense, US government leadership announced its intentions to expand protection to these global commons, specifically with a commitment to the Asia-Pacific region. Supporting that rebalance to the Pacific, Joint operations began to focus more on air-sea operations that are based on the concept of the Air Sea 
Battle. ${ }^{1}$ Providing Army support to these air-sea operations in the US Pacific Command (USPACOM) area of responsibility (AOR) presents challenges due to the region's geographic vastness and because it is perceived to be primarily an air and maritime domain focused area. ${ }^{2}$ As stated in the US Army Pacific’s (USARPAC’s) White Paper on partnering in the Pacific, “USARPAC, America's Theater Army in the Pacific, is the decisive force to execute a sustained and unified land-based security strategy in support of the USPACOM Commander's Theater Campaign Plan.” ${ }^{3}$ While these challenges and requirements present an increased necessity for the US Army's presence in the region, the versatility of Army forces, and Army aviation in particular, are limited by aircraft range, airbase locations, and maintenance and refuel capabilities. In 2012, The Chief of Staff of the Army, General Ray Odierno, asked the US Army Aviation Center of Excellence (USAACE) to study the capability of Army aviation supporting USPACOM by operating from naval vessels. The intent is not to replace US Marine Corps (USMC) and US Navy (USN) capabilities, but to augment, to increase capacity, or to provide unique capabilities not resident in the other services. USAACE's initial analysis concluded that Army aviation is capable of maritime operations in scalable and tailorable configurations. ${ }^{4}$ Although not defined in current doctrine, the term scalable is used to describe forces that are able to be changed in size or scale, and tailorable is used to describe forces that are able to be adapted

${ }^{1}$ Air-Sea Battle: Service Collaboration to Address Anti-Access \& Area Denial Challenges (Washington, DC: Government Printing Office, 2013), 1. The Air Force and Navy together developed a new joint air-sea battle concept for defeating adversaries across the range of military operations, including adversaries equipped with sophisticated anti-access and area denial capabilities. The concept addresses how air and naval forces will integrate capabilities across all operational domains-air, sea, land, space, and cyberspace - to counter growing challenges to U.S. freedom of action.

${ }^{2}$ Partnering in the Asia-Pacific Theater: The U.S. Army, Pacific Theater Engagement Strategy White Paper (Washington, DC: Government Printing Office, 2012), 2.

${ }^{3}$ Ibid.

${ }^{4}$ Henry C. Perry and Brian Hummel, "Preparing for Maritime Contingency Operations," Aviation Digest October-December (2013): 25. At the time of this article's publication, LTC Henry Perry was the Battalion Commander and Major Brian Hummel was the Executive Officer of the 4-227th Attack Reconnaissance Battalion that conducted shipboard operations in the CENTCOM AOR in 2013. 
for a particular purpose. In today's operational environment, the Army now wants its forces to quickly and effectively respond to small conflicts, isolated acts of aggression, and natural disasters in the Pacific theater.

Based on the developing requirement for ship-based employment of Army aviation assets, this monograph seeks to determine what should the operational role be for Army aviation in a maritime theater, specifically the USPACOM AOR? With the implications of current strategy in the Pacific theater, the historical precedent of successful Army aviation shipboard operations, and the exploration of potential employment options and force packages, the operational role for Army aviation in the USPACOM AOR is that of operating as scalable and tailorable task forces operating from Navy vessels and platforms supporting the full range of military operations.

In order to determine Army aviation's operational role in the Pacific Theater, four questions must be answered. First, what are the implications of the "pivot to the Pacific" and the rebalancing of US strategic focus to the Asia/Pacific region for Army aviation? This rebalancing is not a just an air and sea power area of concern, it has major implications to all components including land power and, specifically, Army aviation. Second, through the use of historical case studies, how did Army aviation successfully utilize ship-based employment during past operations? Army aviation, by utilizing ship-based employment of assets during operations in the Persian Gulf, Haiti, and Libya, facilitated operational reach and decisive operations for the operational commander. Third, what does current Joint and Army doctrine address in regards to the employment of Army aviation assets in a maritime environment? Joint and Army doctrine cover most general aspects of shipboard operations, with joint doctrine being more current and relevant than Army doctrine when the two are compared. Fourth, what are the current and projected near-term capabilities of Army aviation in a maritime theater of operations? Current and projected near-term Army aviation capabilities include providing aviation support to retain naval freedom of navigation, reconnaissance and security operations, small vessel interdiction, 
and attack of land and sea based targets. Along with these, is the capability to support to in-land raid or strike package delivery, maritime vertical envelopment, search and rescue, and humanitarian assistance and disaster relief.

Army rotary wing aircraft have operated from Navy ships since the latter part of World War II - and they continue to do so today. Historically, Army aviation assets have been employed from ships when access to operational areas by land, sea, or air was limited, when the capacity of USN and USMC aviation was exceeded by mission demands, or when Army aviation provided a unique capability not resident in USN or USMC aviation. Operating from aboard ships, Army aviation can conduct a variety of reconnaissance, security, attack, air assault, air movement, and air medical evacuation (MEDEVAC) missions. These missions can be done in support of typical doctrinal USN and USMC operations, such as Small Target/Mine Detection, Strike Coordination and Reconnaissance, Vertical Replenishment, and Vertical Onboard Delivery. ${ }^{5}$ In select circumstances, Army aviation can be employed from shipboard as a supported force - or as an element of a larger Army supported force - to conduct littoral reconnaissance, interdiction attacks, and air assaults to gain and maintain access to an operational area, or conduct larger scale air movement of supplies, equipment, and personnel in support of humanitarian or noncombatant evacuation operations.

While Army aviation elements can operate from onboard ships, Army helicopters and Army aviation logistical assets (ammunition, ground support equipment, life support equipment, and aircraft survivability equipment) are not specifically designed for shipboard operations. ${ }^{6}$ These Army assets lack the design features typically found in seagoing aircraft and equipment

${ }^{5}$ MCRP 3-25J/NTTP 3-20.8/AFTTP 3-2.74, Air Operations in Maritime Surface Warfare (Washington, DC: Government Printing Office, 2014), 2. This multi-service tactics, techniques, and procedures publication is a project of the Air Land Sea Application Center.

${ }^{6}$ Geoffrey C. Lambert and Mark M. Huber, "Joint Shipboard Helicopter Operations," Joint Forces Quarterly Winter 2000-01 (2001): 85. 
which mitigate some of the hazards, reduce the impact of the maritime environment on aircraft readiness, and enhance the efficiency of shipboard operations. Although not optimized for shipboard employment, Army aviation assets can operate effectively onboard ships with the proper training, preparation, recognition of limitations, and application of prudent risk management actions.

Shipboard employment of Army aviation will incur a number of costs not typically experienced when employed on land. There are special training qualifications and certifications that aircrews must have to operate on ships and fly overwater, and units must train on the unique tactics, techniques, and procedures associated with ship-based employment. ${ }^{7}$ Units will require extra equipment in addition to their typical modified table of organization and equipment allocations-Aviation Life Support Equipment associated with overwater operations, in particular. An increased sustainment burden is to be expected, as the maritime environment is particularly harsh for aircraft. In addition, the operational 'opportunity' cost of any USN and USMC assets displaced from the ships to accommodate Army aviation assets must be considered. The costs of operating Army aircraft from naval vessels will vary based on the scope, scale, and duration of any shipboard employment.

Despite the potential costs and limitations, Army aviation offers a very real capability for shipboard employment. Under the right circumstances, such a capability can be invaluable to a Joint Force commander. In view of recent shifts in emphasis in the strategic guidance, further study and development of this capability seems prudent. This monograph explores potential employment options and force packages for Army aviation operating from Navy vessels and platforms. It assesses the operational utility of such employment and considers a number of implications and impacts associated with shipboard operations.

\footnotetext{
7 Joint Publication 3-04, Joint Shipboard Helicopter and Tiltrotor Aircraft Operations (Washington, DC: Government Printing Office, 2012), II-21.
} 


\section{Part 1}

\section{Pacific Rebalance}

The Pacific Rebalance began in the fall of 2011 when the Obama administration announced an expansion and intensification of its role in the Asia-Pacific Region. Along with several other steps, the administration signaled that it was placing a higher level of priority to the region shifting U.S. foreign policy away from its focus on the Middle East. On 17 November 2011, the President of the United States addressed the Australian Parliament in Canberra, where he expanded upon the objectives of the new US security strategy unveiled the day before in Darwin. Alongside the Australian Prime Minister, Julia Gillard, President Barack Obama disclosed the details of a new defense agreement between the United States and Australia that initiated the continuous stationing of approximately 2,500 US Marines (via rotational deployments) to Darwin starting in mid-2012. ${ }^{8}$ On 4 April 2012, the first contingent of approximately 200 Marines arrived in Darwin to signal the start of this new phase in the strategic relationship between the United States and Australia. ${ }^{9}$

In his speech to the Australian Parliament, the President stated that this new security strategy reflected a "broader shift. After a decade in which we fought two wars that cost us dearly, in blood and treasure, the United States is turning our attention to the vast potential of the Asia Pacific region... Our new focus on this region reflects a fundamental truth - the United States has been, and always will be, a Pacific nation.”10 According to President Obama:

${ }^{8}$ Donna Miles, “Obama Announces Expanded U.S. Military Presence in Australia,” U.S. Department of Defense, November 16, 2011, accessed September 15, 2014, http://www.defense.gov/news/newsarticle.aspx?id=66098.

${ }^{9}$ Donna Miles, “Rotational Force in Australia Paves Way for Big Growth in 2014,” U.S. Department of Defense, September 24, 2013, accessed September 15, 2014, http://www.defense.gov/news/newsarticle.aspx?id=120844.

10 "Remarks by President Obama to the Australian Parliament," The White House, November 17, 
Our presence and mission in the Asia Pacific (is) a top priority... Indeed, we are already modernizing America's defense posture across the Asia Pacific. It will be more broadly distributed -- maintaining our strong presence in Japan and the Korean Peninsula, while enhancing our presence in Southeast Asia. Our posture will be more flexible -- with new capabilities to ensure that our forces can operate freely. And our posture will be more sustainable, by helping allies and partners build their capacity, with more training and exercises. ${ }^{11}$

The President also noted that the policy is based on the perceived desire by many Asia-Pacific countries for continued strategic reassurance in the face of a rising and increasingly assertive and aggressive China.

A month after the President's address in Australia, the U.S. Department of Defense formally unveiled the renewed emphasis on the Asia-Pacific region with the release of Sustaining U.S. Global Leadership: Priorities for 21st Century Defense. According to the new strategic guidance:

While the US military will continue to contribute to security globally, we will of necessity rebalance toward the Asia-Pacific region. Our relationships with Asian allies and key partners are critical to the future stability and growth of the region. We will emphasize our existing alliances, which provide a vital foundation for Asia-Pacific security. We will also expand our networks of cooperation with emerging partners throughout Asia-Pacific to ensure collective capability and capacity for securing common interests. $^{12}$

The new strategic guidance also highlighted the importance of the US military's ability to project power despite anti-access and area denial challenges.

The US' renewed strategic emphasis on the Asia-Pacific region was also emphasized in a speech made at the Shangri La Dialogue in Singapore on 4 June 2011 by the US Secretary of Defense, Robert Gates. In that speech, Secretary Gates disclosed US plans to station new USN

2011, accessed June 15, 2014, http://www.whitehouse.gov/the-press-office/2011/11/17/remarks-presidentobama-australian-parliament.

11 "Remarks by President Obama to the Australian Parliament."

${ }^{12}$ Sustaining U.S. Global Leadership: Priorities for 21st Century Defense, (Washington, DC: Government Printing Office, 2012), 2. Emphasis in the original. 
Littoral Combat Ships (LCS), on a continuous rotational basis, to Singapore as part of an effort to strengthen “our bi-lateral defense relationship” and to pursue “more operational engagement.” 13 On 1 March 2013, the first LCS, USS Freedom (LCS-1) sailed from its homeport of San Diego, California, bound for Singapore. Freedom was embarking upon an eight-month deployment to that Southeast Asian nation and making good on then-Secretary Gates’ commitment from 2011. According to the USN, Freedom would be conducting “maritime security operations with regional partners and allies.” ${ }^{14}$ With Freedom's maiden deployment and the start of rotational Marine deployments to Darwin, the American rebalancing to Asia-Pacific appeared to begin in earnest.

Looking at a map, The PACOM AOR seems to be dominated by the Pacific Ocean and its sea lines of communications. This leads to the misperception that the AOR is solely dominated by the air and maritime domains. When one looks closer at the compositions of the region's militaries, the forces of the land domain are most often the largest service and most influential. As stated in the US Army Pacific's (USARPAC) description of the AOR, “today, 21 of 27 nations in the Asia-Pacific with armed forces have an army chief of defense and, of the 36 Asia-Pacific nations and territories, 26 have armed forces where the army is the largest service all in a region that includes seven of the world's ten largest armies.” ${ }^{15}$ USARPAC envisions partnerships with the strong land forces in the AOR to be the means the Army uses to support the rebalance to the region.

13 "Remarks by Secretary Gates at the Shangri-La Dialogue, International Institute for Strategic Studies, Singapore,” US Department of Defense, June 3, 2011, accessed June 15, 2014, http://www.defense.gov/transcripts/transcript.aspx?transcriptid=4831.

${ }^{14}$ Christopher Farrington, “USS Freedom Departs on Maiden Deployment,” US Navy, 1 March 2013, accessed June 20, 2014, http://www.navy.mil/submit/display.asp?story_id=72459.

${ }^{15}$ Partnering in the Asia-Pacific Theater: The U.S. Army, Pacific Theater Engagement Strategy White Paper, 2. 
In support of this rebalancing effort USARPAC has taken steps to provide responsive land forces postured to support operations throughout the theater. USARPAC has allocated the following strategy imperatives towards this effort: "provide ready forces and capabilities to meet requirements throughout the region, set the theater for security and stability, maintain contingency forces, enhance air and missile defense capabilities, streamline command relationships, and build ties with regional armies.” ${ }^{16}$ Due to the wars in Iraq and Afghanistan over the last 10 years, USARPAC was narrowly focused on potential conflicts on the Korean Peninsula, but now must have forces available for contingencies throughout the entirety of the AOR.

USARPAC's stated mission is to “posture and prepare the force for unified land operations, respond to threats, sustain and protect the force, and build military relationships that develop partner defense capacity in order to contribute to a stable and secure USPACOM area of responsibility." ${ }^{17}$ In order to execute this mission, USARPAC is postured with the following forces: one corps headquarters (I Corps), two divisions (25th and 2nd Infantry Divisions), nine Brigade Combat Teams, 11 multi-function brigades, and two Combat Aviation Brigades. The 25th Combat Aviation Brigade is located at Schofield Barracks, Hawaii and the 2nd Combat Aviation Brigade is located at Camp Humphreys, Korea.

As part of the strategy to support the rebalancing effort, and of importance to Army aviation, USARPAC “anticipates an increase in aviation, both manned and unmanned, fully integrated with air assets of the other services in support of AirSea Battle operations.” ${ }^{18}$ In

${ }^{16}$ Vincent K. Brooks and Charlie H. Kim, “U.S. Army Pacific Makes Major Moves to Face Regional Challenges,” Army Magazine, April 2014, 32. General Vincent K. Brooks is currently the Commander of US Army Pacific.

17 “USARPAC Mission and Vision,” US Army Pacific, accessed November 18, 2014, http://www.usarpac.army.mil/misvis.asp.

${ }^{18}$ Vincent K. Brooks and Charlie H. Kim, 36. 
support of this integration, Army aviation will require the ability to operate shore-to-ship or shipto-shore from a carrier strike group, expeditionary strike group, or surface strike group. This provides the combatant commander flexibility when deciding how to project combat power from a sea-based platform to execute missions throughout the full range of military operations. The expectation of joint operations for Army aviation will see Army aircraft operating from USN ships in Pacific waters, but as history shows, this is not a new concept for Army aviation.

\section{Part 2}

\section{Army Shipboard Operations Historical Case Studies}

The concept of Army aircraft operating from US naval vessels has already proven successful in past combat operations. With Operation Earnest Will in the Persian Gulf, Operation Uphold Democracy in Haiti, and Operation Ellamy in Libya as historical precedent, the concept of employing Army aviation helicopters in conjunction with the mobility of naval ships can be validated and shown to have implications for future operations. These three historical cases

provide examples where the Army eschewed traditional land-based operations and instead employed its aviation assets from naval platforms.

\section{Operation Earnest Will}

Operation Earnest Will began during the Iran-Iraq War fought in the 1980s. As the war between the two countries slowed to a stalemate, both sides began to seek an advantage by attacking each other's economic source of income - oil. Iran became convinced that Saudi Arabia and Kuwait were supporting the Iraqi war effort and in 1986 began using naval mines, small attack boats, and Silkworm anti-ship missiles to harass and destroy neutral shipping that was 
passing through the Persian Gulf. ${ }^{19}$ Iran's attempt to prevent the free passage of shipping through the Gulf violated the US's stated political policy for the Middle East. ${ }^{20}$

In December of 1986, President Ronald Regan authorized the “reflagging” of Kuwaiti oil tankers, and then provided them with US naval protection in July 1987. This US naval protection came in the form of escort missions provided by ships in the region. However, during the first escort mission, on 24 July 1987, the oil tanker Bridgeton struck an Iranian mine. Since the presence of US ships alone did not deter Iranian aggression, the US began a more robust response. To counter the Iranian mine and small boat threat, the US deployed helicopters and small specialized ships, augmented with navy special forces teams, to the region. ${ }^{21}$ The first helicopters to the region were the Army's rocket and mini-gun equipped MH-6s from Task Force (TF)-160. TF-160 was an Army aviation unit specifically designed to support special operations. Flying from Navy ships in small formations, the MH-6s conducted night patrols to search for Iranian mines and to find small Iranian attack boats. ${ }^{22}$ By September, Iranian activity in the area became more aggressive, resulting in a strategy shift from observation to offensive attack operations. During the next few months, the MH-6 teams were successful in attacking Iranian mine laying ships, supporting Navy special warfare team boarding operations, and destroying

\footnotetext{
${ }^{19}$ John W. Partin, Special Operations Forces in Operation Earnest Will/Prime Chance I, (Hulburt Air Force Base, FL: US Special Operations Command, History and Research Office, 1998), 5.

${ }^{20}$ Jimmy Carter, "The State of the Union Address Delivered Before a Joint Session of the Congress,” The American Presidency Project, January 23 1980, accessed 15 September, 2014, http://www.presidency.ucsb.edu/ws/?pid=33079. President Jimmy Carter articulated U.S. strategic policy, called the Carter doctrine, for the Middle East in his 1980 State of the Union Message: "Let our position be absolutely clear: An attempt by any outside force to gain control of the Persian Gulf region will be regarded as an assault on the vital interests of the United States of America, and such an assault will be repelled by any means necessary, including military force.”

${ }^{21}$ Partin, 11.

${ }^{22}$ David B. Crist, “Joint Special Operations in Support of Earnest Will,” Joint Force Quarterly (Autum-Winter):16.
} 
Iranian fast attack boats. ${ }^{23}$ However, the demands of Operation Earnest Will eventually drained TF-160's resources. In February 1988, the Army deployed OH-58D helicopters from the 118th Aviation Battalion as a replacement unit for TF-160. This new force was named Prime Chance II.

The OH-58Ds of the 118th Aviation Battalion had several advantages over the MH-6s. These advantages included a greater FLIR sensor capability, auto-focusing infrared imaging sensors, and laser range finders and designators for Hellfire missiles. While not as small or as quiet as the MH-6s, the OH-58D also had a greater firepower capability. ${ }^{24}$ From February to July 1988, the OH-58Ds responded successfully to several Iranian attacks. The last significant operation occurred on 12 July 1988, when two OH-58Ds destroyed an Iranian patrol boat that was attacking a Panamanian tanker. ${ }^{25}$

By August 1988, Iran ended its unsuccessful “Tanker War” one month after accepting a United Nations cease-fire with Iraq. Summing up the operation, Dr. John W. Partin states in his history of Operation Earnest Will, "the United States had succeeded in preventing an Iranian economic blockade of Kuwait.”26 The success of Operation Earnest Will was due in large part to the non-traditional use of Army aviation. It was not a doctrinal mission for Army aviation to employ from USN ships and conduct missions preventing a hostile force from controlling Persian Gulf shipping, but, as the success of Operation Earnest Will illustrates, conducting operations that allow strategic freedom of navigation, is certainly an Army aviation capability.

\section{Operation Uphold Democracy}

In September of 1994, the United States, under the auspices of United Nations Resolution 940, deployed forces into Haiti. Planning for a possible military operation into Haiti had been

\footnotetext{
${ }^{23}$ Partin, 118.

${ }^{24}$ Crist, 21.

25 Ibid.

${ }^{26}$ Partin, 114.
} 
considered for several years, including operational plans for a permissive intervention and a nonpermissive invasion. Most of the planning by the Joint Task Force Command, the XVIII Airborne Corps, concerned a non-permissive invasion utilizing 82nd Airborne Division paratroopers as the main effort. Within a few days of the invasion, former President Jimmy Carter led a delegation to meet with the military dictator in the capital of Haiti, Port-au-Prince. The military junta agreed to change its hard line position and the XVIII Airborne Corps had to quickly adapt the invasion plan into an intervention plan. The aims of the operation were to restore civil order, and assist in the transition to a democratic government that included the return to office of the democratically elected president. ${ }^{27}$

As part of this intervention effort, two aircraft carriers, the USS America and the USS Dwight D. Eisenhower, left Norfolk, Virginia on 14 September 1994 on a non-standard mission. All of the fixed-wing aircraft and most of the air-wing personnel assigned to each of the aircraft carriers had been removed to make room for Army assault forces and the Army aviation helicopters to carry and support those assault forces. ${ }^{28}$ Army special operations aircraft operated from USS America and conventional Army helicopter units from the 10th Mountain Division flew personnel ashore from the USS Eisenhower. Over the course of the operation, the USS Eisenhower was home to 57 helicopters from the 10th Aviation Brigade, which included 20 UH60s for the planned assault. ${ }^{29}$

One infantry brigade of about 4,000 soldiers had been loaded onto the USS Eisenhower, and Soldiers from the 10th Mountain Division, using US Army helicopters, conducted the initial

${ }^{27}$ Walter E. Kretchik, Robert F. Baumann, and John T. Fishel. Invasion, Intervention, "Intervasion": A Concise History of the U.S. Army in Operation Uphold Democracy (Fort Leavenworth, Kansas: U.S. Army Command and General Staff College Press, 1998), ix.

${ }^{28}$ E.D. McGrady and Robert E. Sullivan, Operation Uphold Democracy: Observations on Joint Assault Operations From a CV (Alexandria, VA: Center for Naval Analysis, 1996), 1.

${ }^{29}$ Ibid., 6. 
air movements into Haiti off the deck of the carrier on 19 September. Two battalions of 10th Mountain Division Soldiers were air lifted onto the Port-au-Prince International Airport to initiate Operation Uphold Democracy. With the permissive environment offered by the Haitian military junta, facilities in Port-au-Prince and selected other cities in Haiti were occupied and used for troop arrival, departure, and logistic support bases.

Summing up the operation, the authors of the history of Operation Uphold democracy stated, "This innovative use of the carriers significantly enhanced the flexibility of the Joint Task Forces (JTF) at the strategic and operational level and permitted a much more rapid transition from a forced-entry plan to a revised permissive intervention plan.” ${ }^{30}$ Because of the options that sea basing these forces provided, the JTF commander gained increased flexibility by having a robust force offshore that he could rapidly send anywhere in Haiti.

\section{Operation Ellamy}

In February 2011the Libyan regime of Colonel Muammar Gadhafi stepped up its military campaign against rebel forces, in defiance of United Nations (UN) Security Council Resolution 1970. The pressure to impose a no-fly zone - which would require attacking the regime’s air defenses - began to mount. On 17 March, the UN Security Council, with China, Russia, Germany, Brazil and India abstaining, passed Resolution 1973 authorizing nations to "take all necessary measures ... to protect civilians and civilian populated areas under threat of attack in the Libyan Arab Jamahiriya, including Benghazi, while excluding a foreign occupation force of any form on any part of Libyan territory.” ${ }^{31}$ The deteriorating situation in the city of Benghazi triggered the first air action of the campaign as the French Air Force struck regime forces around

\footnotetext{
${ }^{30}$ Walter E. Kretchik, Robert F. Baumann, and John T. Fishel, 164.

31 “UN Security Council Resolution 1973," United Nations, March 17, 2011, accessed September 10, 2014, http://www.un.org/press/en/2011/sc10200.doc.htm. The Libyan Arab Jamahiriya was the authoritarian regime in Libya ruled by Colonel Mu'ammar al-Qadhafi from 1969 until 2011.
} 
the city on 19 March 2011. Forces from the United Kingdom (UK) participated in this operation as well.

Operation Ellamy was the name given to the UK's effort in support of the overall North Atlantic Treaty Organization (NATO) led Operation Unified Protector. In May 2011, in support of this operation, the resolve to deploy combat helicopters gradually grew both in the UK and France in order to further restrain the ground maneuvers of Gadhafi's forces. Attack helicopters also had a role in the campaign with the British Army fielding the AH-64 Apache and the French providing their country’s attack helicopter, the Tigre. AH-64s flew from the Royal Navy’s helicopter carrier HMS Ocean while Tigre operated from the Tonnere. ${ }^{32}$

On the night of 3 June, British combat helicopters for the first time as part of Operation Ellamy engaged ground targets. Five Apache helicopters of 656 Squadron, 4 Regiment Army Air Corps, launched from the HMS Ocean and operated in the area of Brega, helping to disrupt enemy forces along the front line in eastern Libya. ${ }^{33}$ Despite facing hostile fire the night prior, HMS Ocean again launched its combat helicopters the next night to engage multiple launch rocket systems. ${ }^{34}$ The British combat helicopters operated in close cooperation with fixed-wing aircraft, the latter gathering intelligence both to select targets and to provide assessments of potential surface-to-air-missile threats. The AH-64s also remained on stand-by to launch complementary strikes. ${ }^{35}$

\footnotetext{
${ }^{32}$ Lessons Offered From the Libya Air Campaign,” Royal Aeronautical Society (July 2012): 12.

33 “Libya: UK Apache Helicopters Used in NATO Attacks,” BBC News, June 4, 2011, accessed September 10, 2014, http://www.bbc.co.uk/news/uk-13651736.

34 “HMS Bangor En Route to Libya," UK Ministry of Defence, June 7, 2011, accessed September http://www.mod.uk/DefenceInternet/DefenceNews/MilitaryOperations/HmsBangorEnRouteToLibya.htm.

35 “Good Progress Seen in Libya Operations," UK Ministry of Defence, June 24, 2011, accessed http://www.mod.uk/DefenceInternet/DefenceNews/MilitaryOperations/GoodProgressSeenInLibyaOperatio
} 10, 2014, September 10, 2014, ns.htm. 
British Army Apache helicopters also engaged both ground and maritime targets in the area of Misrata. On a raid in early June, they first destroyed high-speed inflatable boats attacking the harbor of Misrata and then opened fire on a ZSU-23-4 self-propelled anti-aircraft gun near Zlitan as well as a number of armed vehicles, displaying the flexibility of helicopter operations in this particular theatre. ${ }^{36} \mathrm{~A}$ total of 22 Apache missions (49 combat sorties) were flown with 99 Hellfire missiles fired along with 4,800 rounds of 30mm cannon and 16 rockets. ${ }^{37}$

As the results of Operation Ellamy show, Army attack aircraft can conduct successful independent deep operations using naval vessels as launch and/or recovery platforms. Libya also provided an opportunity to test Air Sea Battle thinking, and embarking Apache helicopters on HMS Ocean demonstrated what could be achieved by the joint integration of Army and Navy assets. Understanding past examples of shipboard employment is only one part of determining the overall operational role of Army aviation in the Pacific theater. One must also understand how current Joint and Army doctrine influences force structure, training, and operations as it relates to shipboard operations.

\section{Part 3}

\section{Shipboard Operations Doctrine Review}

Defining the role of Army aviation in the Pacific theater continues with an assessment of current relevant doctrine. In order to understand how Army aviation can help an operational commander dominate an area of operations, it is essential to understand both the Joint Force's and the Army's doctrinal principles for the employment of aviation assets in a maritime environment.

\footnotetext{
36 “RAF Destroys Nine of Gaddafi’s Underground Storage Bunkers in Libya,” UK Ministry of Defence, June 13, 2011, accessed September 10, 2014,

http://www.mod.uk/DefenceInternet/DefenceNews/MilitaryOperations/RafDestroysNineOfGaddafisUnder groundStorageBunkersInLibya.htm.

37 “Lessons Offered From the Libya Air Campaign,” 12.
} 
JP 1-02, Department of Defense Dictionary of Military and Associated Terms, defines doctrine as the "fundamental principles by which the military forces or elements thereof guide their actions in support of national objectives. It is authoritative but requires judgment in application." ${ }^{38}$ Doctrine not only gives the Army a guide for conducting operations, but it also sets the direction for organizational structure and training.

Joint and Multi-Service Doctrine

Joint Publication (JP) 3-04, Joint Shipboard Helicopter and Tiltrotor Aircraft Operations, which was most recently updated and published in 2012, describes the unique aspects of joint shipboard operations. The publication covers all facets of pre-deployment, embarkation, and debarkation planning for joint shipboard operations, and addresses shipboard command authorities, flight/hangar deck operations, and sustainment considerations. JP 3-04 also provides general guidance for integrating aircraft from all the services aboard air-capable ships, amphibious assault ships, and aircraft carriers for operations from the sea. ${ }^{39}$

In addition to the overall description of joint shipboard operations, JP 3-04 identifies the many areas where Army aviation tactics, techniques, and procedures (TTPs) are divergent from those utilized by the Navy aboard ship. To ensure that planners account for these variances, the manual discusses shipboard refueling differences, aircrew training requirements, electromagnetic interference considerations, ammunition storage issues, and command and control space limitations. ${ }^{40}$ Being cognizant of these differences prior to the commencement of joint shipboard

38 JP 1-02, Department of Defense Dictionary of Military and Associated Terms (Washington, DC: Government Printing Office, 2010), 78.

${ }^{39}$ JP 3-04, vii.

${ }^{40} \mathrm{JP}$ 3-04, Chapter II. 
operations allows for both Army and Navy personnel to have a working knowledge of each other's capabilities and operational concepts. ${ }^{41}$

Also of relevance because of its subject matter, is the multi-service publication MCRP 325J/NTTP 3-20.8/AFTTP 3-2.74, Air Operations in Maritime Surface Warfare, published in 2014. This publication is intended to provide multi-service TTPs for the integration of air assets supporting maritime surface warfare, and describes the various missions that can be conducted by joint or coalition air assets in the maritime domain in support of the Joint Force Commander. ${ }^{42}$ It outlines the unique nature of maritime air operations and describes the challenges faced by planners and operators alike. Of note, the Army is the only service that is not signatory to this publication, and as such is not required to incorporate the procedures from it into the Army's training and doctrine publications.

\section{Army Doctrine}

As part of the Army’s doctrine modernization plan, called Doctrine 2015, Army aviation is in the process of updating its respective doctrine to align with unified land operations, the fundamental principles of decisive action, and the Army's core competencies of combined arms maneuver and wide area security. The planned capstone doctrine for Army aviation is Field Manual (FM) 3-04 Army Aviation, but this manual has yet to be published. The current capstone aviation doctrine is FM 1-100 Army Aviation Operations, which was last updated in 1997. Based on the many structural and operational changes that have occurred within Army aviation since 1997, this manual should be considered obsolete.

${ }^{41}$ Based on its core mission offensive amphibious employment, the USMC has several doctrinal publications related to amphibious shipboard operations, including Marine Corps Warfighting Publication 3-31.5/Navy Tactics, Techniques, and Procedures 3-02.1M, Ship-to-Shore Movement. This publication discusses the doctrine, command relationships, tactics, techniques, and procedures for planning and executing ship-to-shore movement during amphibious operations.

${ }^{42}$ MCRP 3-25J/NTTP 3-20.8/AFTTP 3-2.74, 1. 
FM 1-100 makes only one reference to shipboard operations. In the section discussing future doctrine, the manual describes how Army aviation will be deployed "by strategic air or sea lift, self-deployment, with a maritime force aboard aircraft carriers, or by any combination of those means.” ${ }^{43}$ There is no further discussion on the actual operational level implementation of this shipboard force projection capability. The next reference to shipboard operations in the hierarchy of Army doctrine is in FM 3-04.111, Aviation Brigades, which was published in 2007. In a section of chapter three called "Special Environments," the manual delves slightly deeper into the topic of shipboard operations over the course of two paragraphs, but as with FM 1-100, it only addresses tactical planning considerations and does not offer any operational level planning guidance. Based on FM 3-04.111's intended audience of “all aviation commanders, staffs, and any U.S. military personnel expecting to conduct operations with Army aviation units,” one should expect further discussion on operational applications of shipboard operations. ${ }^{44}$

FM 1-564, Shipboard Operations, which was published in 1997, outlines Army tactical procedures for shipboard helicopter operations. The manual is used to coordinate, plan, execute, and teach shipboard operations. It additionally provides information for developing a standardized, progressive program to train crews to proficiency on shipboard operations. As stated in its preface, the manual is intended for the use of units and aircrews at the tactical level conducting shipboard operations. ${ }^{45}$ As with FM 1-100, this manual has also been outdated for many years, and should be re-written to reflect the current joint and Army doctrinal principles.

Based on the above review of both Joint and Army shipboard operations doctrine, one can conclude that Army doctrine requires updating to reflect and incorporate the myriad of changes in joint operations since 1997. Much of the Army doctrine on shipboard operations is

${ }^{43}$ FM 1-100, Army Aviation Operations (Washington, DC: Government Printing Office, 1997), vii. Emphasis added.

${ }^{44}$ FM 3-04.111, Aviation Brigades (Washington, DC: Government Printing Office, 2007), viii.

${ }^{45}$ FM 1-564, Shipboard Operations (Washington, DC: Government Printing Office, 1997), v. 
focused on the tactical level and provides little guidance to the operational commander on the implementation of the tactics described. Joint doctrine is more relevant based on the currency of its publication and it does more to inform the operational level commander on the integration and implementation of shipboard Army aviation assets in the maritime environment.

\section{Part 4}

\section{Army Aviation Shipboard Operations}

Army aviation assets are optimized for land operations. Under most circumstances, even for overwater operations, land basing is the preferred option. This monograph, however, assumes that a land base is either not readily available or other circumstances dictate employment from onboard Navy vessels. While Army aviation assets have been employed successfully from naval vessels/platforms as shown through past historical examples, Army aircraft and related equipment are not optimized for long-term maritime operations.

Army aircraft lack the attributes of sea-going aircraft, such as rotor brakes, automaticfolding blades, electromagnetic interference (EMI) hardening, and reinforced mooring points. ${ }^{46}$ Army aviation assets can be considered 'shipboard capable,' but fall short of being 'shipboard compatible' like most USN and USMC aircraft and equipment. Achieving 'shipboard compatibility’ would require significant investment of funds and time in order to modify Army aircraft and equipment. Based on the current fiscal environment, this monograph assumes that such an investment is not currently affordable and limits the exploration to current and programmed Army aviation assets.

Both conventional and Army Special Operations aviation units have demonstrated in the past that they are capable of successfully conducting shipboard operations. Army Special

${ }^{46}$ Geoffrey C. Lambert and Mark M. Huber, "Joint Shipboard Helicopter Operations," Joint Forces Quarterly Winter 2000-01 (2001): 85. 
Operations aviation units, such as the 160th Special Operations Aviation Regiment, maintain elements that are trained and qualified for shipboard employment, and their shipboard employment capabilities and tactics are well developed. ${ }^{47}$ Conversely, conventional Army aviation shipboard capabilities are more ad hoc and not grounded in current Army doctrine, and rely more on local tactics, techniques, and procedures. Based on these doctrinal shortcomings, this section explores potential conventional Army aviation employment options.

\section{Potential Shipboard Operations}

While Army aviation formations can be called upon to support a wide spectrum of operations when employed from Navy ships, they will do so by continuing to execute Army aviation's core missions of attack, reconnaissance, security, air assault, air movement and air MEDEVAC. ${ }^{48}$ Additionally, Army aviation can operate as either a supporting force, the supported force, or as part of a larger Army element that is itself the supported force.

\section{Supporting Force Operations}

As a supporting force, Army aviation formations will likely be used to augment USN and USMC aviation capacity and will, therefore, likely support Joint aviation shipboard operations. Army aviation attack and reconnaissance helicopters (AH-64D/E and OH-58D) can conduct area reconnaissance or screening missions in the vicinity of a naval task force/group in support of fleet protection and security operations, such as Small Target/Mine Detection and shipping lane reconnaissance and security. At ranges from 80 to 120 nautical miles from the fleet, these assets

${ }^{47}$ Sidney J. Gray III and Charles W. Weigandt, "The 160th SOAR: 20 Years of Army SpecialOperations Aviation," Special Warfare 14, no. 3 (Summer, 2001): 9.

${ }^{48}$ FM 3-04.111, 1-3. 
can conduct reconnaissance and security missions in support of littoral reconnaissance and security and Strike Coordination and Reconnaissance operations. ${ }^{49}$

The basic ‘building block’ employed in these operations is an Attack Weapons Team (AWT) of two aircraft (two AH-64D/E, two OH-58D or one AH-64D/E and one OH-58D). Depending on the scope of the capability augmentation required by USN and USMC aviation, attack/reconnaissance 'packages' can be scaled from the AWT, to platoon (four aircraft), to company/troop (eight to ten aircraft), to battalion/squadron (24-30 aircraft)..$^{50}$ The assumption is made those Army aviation formations larger than a battalion/squadron would not be employed in a supporting force role to the USN or USMC. This is based on the amount of deck space required to support a brigade’s worth of aircraft would necessitate the removal of all Navy and USMC assets, or it would require the use of multiple Navy ships.

The AH-64D/E provides a combat radius (with 30-minute fuel reserve) of approximately 120 nautical miles, and by using an internal auxiliary fuel tank, it can extend its combat radius to 150 nautical miles. ${ }^{51}$ With its extended combat radius (compared to the OH-58D’s 80 nautical mile radius), the AH-64 would be the preferred platform to conduct littoral reconnaissance, interdiction attacks ashore, and air assault security, but as a downside, ships with single landing pads cannot accept the AH-64 due to safety considerations. In terms of capability provided, a company-size element of eight AH-64s would enable the employment of up to three AWTs. Each AWT could be employed for up to approximately eight hours of day operations or five hours of night operations per 24-hour period. The teams could be employed simultaneously or sequentially, depending on mission need.

${ }^{49}$ FM 3-04.126, Attack Reconnaissance Helicopter Operations (Washington, DC: Government Printing Office, 2007), E-1.

${ }^{50}$ Ibid., 1-6.

${ }^{51}$ FM 3-104.126, E-4. 
The $\mathrm{OH}-58 \mathrm{D}$ provides a combat radius of approximately 80 nautical miles and has no capability to employ auxiliary fuel tanks. In addition, as a single-engine helicopter, it incurs greater risk in overwater operations compared to dual-engine helicopters such as the AH-64 and the UH-60. The smaller size of the $\mathrm{OH}-58 \mathrm{D}$, however, makes it suitable for operations from more types of Navy ships than the AH-64. A troop-size element of ten OH-58Ds enables employment of up to four AWTs with the same flight times and employment methods as the AH-64 AWT described above.

Both the AH-64D and the OH-58D aircraft can perform manned-unmanned teaming (MUM-T) with a number of multi-Service Unmanned Aircraft Systems (UAS), to include the Navy’s MQ-8B Fire Scout. The concept of MUM-T is defined as:

The synchronized employment of Soldiers, manned and unmanned air and ground vehicles, robotics, and sensors to achieve enhanced situational understanding, greater lethality, and improved survivability. The concept of MUMT is to combine the inherent strengths of manned and unmanned platforms to produce synergy and overmatch with asymmetric advantages. ${ }^{52}$

Although Army UAS cannot effectively operate from a ship at this time based on launch and recovery limitations, the long range of the MQ-1C Gray Eagle has the potential to facilitate teaming with manned aircraft operating from ships.

As a supporting force, Army aviation lift (UH-60 A/L/M) and cargo (CH-47 D/F) elements can conduct Air Assault missions in support of forced entry or force projection ashore operations. These elements can also conduct air movement operations in support of Vertical Replenishment (the transfer of cargo between ships using helicopters), Vertical On-board Delivery (to ferry personnel, mail, and high-priority cargo, such as replacement parts, on and off a naval ship), at-sea transfer, and selective off-load operations. Army lift and cargo helicopters

\footnotetext{
${ }^{52}$ Mark Taylor, “MUM-T: Training is the Key Ingredient,” Aviation Digest (July-Sep 2014): 5.
} 
can conduct these operations both in support of decisive action operations or humanitarian assistance operations.

The UH-60 provides a combat radius of approximately 115 nautical miles (with a 30minute fuel reserve) and with auxiliary fuel tanks, the combat radius increases to 220 nautical miles. The UH-60 can carry 11 fully equipped troops or has a payload capacity of approximately 8,000 lbs. ${ }^{53}$ The $\mathrm{CH}-47$ combat radius is approximately 100 nautical miles (with a 30 -minute fuel reserve). With one auxiliary fuel tank, the combat radius is extended to approximately 200 nautical miles (with a 30-minute fuel reserve). The CH-47 can carry about 30 fully equipped troops and has a payload capacity of approximately 14,400 lbs. With auxiliary fuel tanks, the troop carrying capacity is reduced to 26 and the payload capacity is reduced to 9,400 lbs. ${ }^{54}$

Army HH-60 aircraft can conduct Air MEDEVAC in support of the fleet or in support of land-based forces. MEDEVAC aircraft have a combat radius of 115 nautical miles (with a 30minute fuel reserve) and, with auxiliary fuel tanks, the combat radius increases to 220 nautical miles. The HH-60 can be configured to carry up to six litter patients. ${ }^{55}$ MEDEVAC aircraft and crews often operate on decentralized joint missions in small teams of two aircraft and up to company size elements of 15 aircraft. No other service component in the US military possesses a comparable capability. MEDEVAC aircraft operating from a ship can perform a variety of medical support missions, from ferrying supplies to transporting essential medical personnel and equipment. Although the HH-60 can conduct Personnel Recovery operations, crews require additional training to do so over water.

${ }^{53}$ FM 3-104.113, Utility and Cargo Helicopter Operations (Washington, DC: Government Printing Office, 2007), C-1.

${ }^{54}$ Ibid., C-7.

${ }^{55}$ FM 3-104.113, C-5. 
The scope of the augmentation required by the USN and USMC will determine the scale of the lift/cargo force package. This may range from a team of two UH-60s, CH-47s, or HH-60s, up to a battalion-size Army aviation task force with a mix of UH-60s, CH-47s, and HH-60s (with attack/recon aircraft in support, if needed). Again, it is deemed unlikely that Army aviation formations larger than a battalion would operate as a supporting force to USN and USMC operations.

Supported Force Operations

Under select circumstances, an Army aviation formation can be embarked as the supported force or as an element of a larger Army formation that is the supported force. It is likely that associated operations would incorporate larger-scale or long-duration air assaults, interdiction attacks, and/or air movement operations requiring battalion or larger Army aviation formations. For air assault (forced entry) operations, an Army aviation task force will likely be an element of a larger Army formation acting as the supported force. For an Infantry battalion task force air assault, the supporting Army aviation force package could consist of eleven UH-60s, three HH-60s, four CH-47s, eight AH-64s, and ten OH-58Ds. ${ }^{56}$ An Infantry Brigade Combat Team air assault operation would require employment of an entire Combat Aviation Brigade’s aircraft. $^{57}$

Force Packages

As described above, the multi-functional Aviation task force consisting of a total of 36 aircraft, along with its associated sustainment elements, could be embarked on two Landing Helicopter Dock (LHD) class Amphibious Assault Ships. The placement of 36 Army aircraft on

${ }^{56}$ 101st Airborne Division (Air Assault) Gold Book (Washington, DC: Government Printing Office, 2010), 7-2.

${ }^{57}$ Ibid. 
the LHDs would displace any USN and USMC aviation assets normally embarked on these vessels. In a supporting role, this task force could be used to augment fleet protection and security operations, shipping lane reconnaissance and security, anti-mine and/or anti-fast attack craft operations, Strike Coordination and Reconnaissance, amphibious assault operations, vertical assault operations, Vertical Replenishment, Vertical Onboard Delivery, MEDEVAC, and Personnel Recovery. In a supported role, this task force can conduct small-scale reconnaissance and security operations, air assault of up to a dismounted infantry battalion, air movement, MEDEVAC, and limited PR operations. Although it consumes considerable ship space, this multi-functional task force provides significant capability and flexibility to the operational commander.

A reconnaissance/attack task force consisting of eight AH-64s, ten $\mathrm{OH}-58$ s and two $\mathrm{HH}-$ 60s (20 total aircraft) can deploy on a LHD and a Landing Helicopter Assault (LHA) Amphibious Assault Ship. In a supporting role, this task force can support amphibious assaults, shipping lane reconnaissance/security, MEDEVAC, PR, and port area security. In the supported role, the task force can also conduct attack, reconnaissance/security, and MEDEVAC operations.

A lift/cargo task force deployed on an LHD and LPD could consist of two CH-47s, Ten UH-60s, and two HH-60s (14 total aircraft). In the supporting role, the task force can perform MEDEVAC, air movement, amphibious assault support, Personnel Recovery, Vertical Replenishment, and Vertical Onboard Delivery. In the supported role, this task force can additionally conduct air movement operations.

\section{Operational Utility Assessment}

Augmenting USN and USMC aviation with embarked Army aviation assets can provide a number of advantages to the Joint Force commander. Typically, as a relatively low-density, high demand set of capabilities, the Joint Force commander rarely has enough maritime aviation at his disposal. Although not optimized for the role, Army aviation assets can enable the Joint Force 
commander to increase the combat power of his maritime aviation forces. This could result in overall greater operational reach across a fleet, and could also enable the Joint Force commander to concentrate USN and USMC aviation assets on the main effort, while covering less critical missions with embarked Army aircraft. Army aviation assets could also be used in conjunction with the USN and USMC to achieve the needed mass and tempo in the execution of an entry operation by enabling a more rapid build-up of combat power than an enemy can counter. Having Army aviation assets readily available on board ships can also enable a more rapid reconstitution of maritime aviation through quickly transitioning Army aviation assets ashore to provide support while USN and USMC assets return to the fleet and prepare for follow-on operations.

Of operational importance to the implementation of Army aviation embarking on naval vessels, is the type and number of ships available for the Army's use within the USN's Pacific Fleet at a given time. Pacific fleet, based in Pearl Harbor, Hawaii, is responsible for all surface ships that operate within the PACOM AOR. In total, Pacific Fleet has 92 surface warfare naval ships that are currently assigned, but only six of those are amphibious assault ships capable of embarking a significant number of Army aircraft. ${ }^{58}$ The Amphibious assault ship is critical to the concept of using naval vessels as a force projection platform. They are the largest of all amphibious warfare ships and they resemble a small aircraft carrier capable of supporting fixed wing, tilt-rotor, and rotary wing aircraft. The Navy currently has in its inventory three classes of the big-deck amphibious ships. The three classes of assault ships are the Wasp class LHD, of which the Navy has eight, the Tarawa class LHA, of which the Navy has one, and finally the new America class LHA, of which the Navy has one (with one also in construction). ${ }^{59}$

\footnotetext{
58 "Pacific Fleet Ships by Class", US Navy, accessed 12 August 2014, http://www.public.navy.mil/surfor/Pages/USNavyPacificFleetShipsbyClass.aspx.

59 "Fact File: Amphibious Assault Ships,” US Navy, accessed 12 August 2014, http://www.navy.mil/navydata/fact_display.asp?cid=4200\&ct=4\&tid=400.
} 
The Wasp class LHD is a multi-purpose amphibious assault ship with the primary mission of employing elements of a landing force through a combination of helicopters and amphibious vehicles. It also has the capability to provide embarked commanders with command and control capabilities for sea-based assault operations. The Wasp class LHD can embark over 40 helicopters when configured for assault only operations. ${ }^{60}$ Pacific Fleet currently has the following four LHDs assigned: the USS Essex, Boxer, Bonhomme Richard, and Makin Island. ${ }^{61}$

The Tarawa class LHA is very similar in design and function to the LHD, but is an older ship with only one remaining in the USN's inventory. It can embark over 25 rotary wing aircraft, but the one remaining LHA ship, the USS Peleliu, is scheduled for decommissioning in 2015. The new America class LHA, first launched in 2012 and commissioned in 2014, is the future of naval amphibious assault ships. With only one ship of this class currently in the fleet, it builds on the capabilities of previous generation LHD/LHA ships and is optimized to support F-35B aircraft operations based on its enlarged deck space and increased aviation fuel capacity. ${ }^{62}$ Both the USS Peleliu and USS America are currently assigned to Pacific Fleet.

These amphibious assault ships were originally designed to support the USMC tasks of respond rapidly to crisis, project power, and conduct littoral maneuver. ${ }^{63}$ As such, these ships traditionally embark USMC aircraft and personnel that form the aviation portion of a Marine Expeditionary Unit (MEU). The MEU is the standard forward-deployed Marine expeditionary organization and can be thought of both as a self-contained operating force capable of missions of limited scope and duration and as a forward-deployed extension of the larger Marine

${ }^{60}$ U.S. Navy Program Guide 2014 (Washington, DC: Government Printing Office, 2014), 96.

61 “SURFPAC's Amphibious Assault Ship (LHD/LHA) Info Page,” US Navy, accessed 18 November 2014, http://www.public.navy.mil/surfor/Pages/AmphibiousAssualtShip.aspx.

62 U.S. Navy Program Guide 2014, 95.

${ }^{63}$ Marine Corps Doctrinal Publication 1-0, Marine Corps Operations (Washington, DC: 2011), 115. 
expeditionary force. The aviation component of the MEU, called the Aviation Combat Element, is typically composed of a reinforced helicopter squadron with transport, utility, and attack helicopters, a detachment of vertical/short takeoff and landing fixed-wing attack aircraft, and other detachments as required. ${ }^{64}$

The MEU’s helicopter squadron provides medium to heavy lift capability, assault support and close air support to ground combat elements of the MEU and to other forces as needed. The helicopter squadron's assets include the CH-53E Super Stallion heavy lift helicopters, AH-1Z Super Cobra helicopter gunships, UH-1Y Huey utility helicopters, and either CH-46E Sea Knight medium lift helicopters or MV-22B Osprey medium tiltrotor aircraft. Typically, the reinforced helicopter squadron of a MEU consists of $12 \mathrm{CH}-46 \mathrm{Es}$ or $12 \mathrm{MV}-22 \mathrm{Bs}$, four $\mathrm{CH}-53 \mathrm{Es}$, four AH1Zs, and three UH-1Ys, for a total of 23 aircraft. ${ }^{65}$

There are seven standing MEUs that routinely deploy in accordance with the Global Force Management Implementation Guidance. The continental US based MEUs are the 11th, 13th, and 15th MEUs from the West Coast and the 22nd, 24th, and 26th MEUs from the East Coast. The 31st MEU is forward assigned and located in Okinawa, Japan. ${ }^{66}$ These seven MEUs normally operate on a steady-state cycle where at any given time three MEUs are deployed, two MEUs are in the build phase, and two MEUs are in the train phase. ${ }^{67}$ This rotational cycle can be disrupted when there is an increased demand for MEUs, such as a protracted conflict in the PACOM AOR. This would potentially overextend USMC aviation assets and create a need for augmentation by Army aviation forces trained and ready to operate from naval vessels. Army

\footnotetext{
${ }^{64}$ Marine Corps Reference Publication 5-12D, Organization of Marine Corps Forces (Washington, DC: Government Printing Office, 1998), 2-4.

${ }^{65}$ Amphibious Ready Group and Marine Expeditionary Unit Overview (Washington, DC: Government Printing Office, 2014), 12-13.

${ }^{66}$ Ibid., 3.

${ }^{67}$ Ibid., 7.
} 
aviation could augment with a complete task force as described previously, or with smaller force packages to supplement a specific area such as attack aircraft or MEDEVAC.

As a supported force element, embarked Army aviation assets can provide the Joint Force with additional entry options in anti-access/area denial situations. Shipboard capable Army aviation assets also offer the Joint Force commander additional options for operational movement and maneuver from the sea. Three major factors, however, have the tendency to limit the operational value of employing Army aviation assets from Navy ships.

The first factor is the lack of sea going design characteristics in Army aircraft and equipment that serve to reduce their efficiency in shipboard operations. The lack of features, such as folding rotor blades and stabilators, causes Army aircraft to consume more deck and hangar space than their USN and USMC counterparts, which leads to a reduction in the number of total aircraft that can be embarked. ${ }^{68}$ Also, the lack of EMI hardening necessitates shutting down elements of a ship's protective systems during select operations (such as rearming) and select flight profiles - thereby increasing risk to the affected vessel. ${ }^{69}$ Additionally, the lack of aircraft marinization measures leaves aircraft vulnerable to the harsh, saltwater environment and drives a significantly higher sustainment effort to preserve the aircraft from the effects of saltwater corrosion. ${ }^{70}$ Proper planning, preparation, and disciplined operations can significantly mitigate a number of these drawbacks.

Second, embarking Army aviation assets onboard Navy shipping will normally incur an opportunity cost in terms of the displacement of USN and USMC assets normally assigned to or embarked on a vessel. In many cases, this will likely be some type of USN or USMC aviation

${ }^{68}$ Geoffrey C. Lambert and Mark M. Huber, "Joint Shipboard Helicopter Operations," Joint Forces Quarterly (Winter 2000-01): 85.

${ }^{69}$ Ibid., 86.

${ }^{70}$ JP 3-04, IV-4. 
asset. When deployed, Navy ships predominantly have their deck and stowage space already accounted for by USN and USMC assets. When embarking Army aviation assets on Navy ships, a careful costs-benefits analysis must be done to ensure the inherent capability lost does not outweigh the capability gained.

Third, the need for naval vessels to stand off significant distances from shore for security purposes serves to limit the full operational potential of Army aircraft flying from Navy ships. Vertical envelopment operations will tend to be limited to the littoral regions near the coastline, unless risk is accepted by moving the Navy task force closer to shore. True 'over the horizon’ strikes or assaults can only be achieved if the helicopters can refuel en route to gain the additional range required. This may be done by using select naval vessels and platforms positioned close to shore as refuel locations. It may also be done by establishing short-duration ‘jump’ Forward Arming and Refueling Points ashore, but both techniques have the potential to incur an increased degree of operational risk and require additional assets.

Impacts/Implications

Shipboard operations necessitate an array of training requirements for individuals and aircrews to achieve required qualifications, certifications, and currency. These include underwater egress training, Deck Landing Qualifications, and flight deck landing pad currency. ${ }^{71}$ Effective shipboard employments also demand unit training on the various tactics, techniques, and procedures associated with shipboard and overwater operations. This includes day/night mission training, as well as overwater aerial gunnery.

The US Army has limited training assets needed to establish a shipboard employment capability. The assets on hand consist primarily of three underwater egress training facilities, aircraft simulators with deck landing capabilities of varying fidelity, and some ad hoc flight deck

${ }^{71}$ JP 3-04, II-21 
landing pads. The most essential assets required for training - actual ships - belong to the Navy. If the Army truly wants to establish and maintain a shipboard employment capability, it will have to proactively engage to schedule Navy ships and training assets for Army aviation use.

Currently, very few Army aviation units have access to the proper Aviation Life Support Equipment (ALSE) gear for overwater operations. Aircrews will require specific over-water ALSE gear, such as a life preserver unit (LPU-40), over-water gear carrier, and an emergency breathing apparatus. ${ }^{72}$ It is likely that some level of additional investment will be required to ensure proper equipping of those formations selected for shipboard employment. The number of units required to be to be shipboard capable at any one time will drive the size of the investment. Army Aviation Survivability Equipment (ASE) are systems that maximize the survivability of Army aircraft against hostile threats, and like the aircraft themselves, are optimized for land combat. As such, ASE has limited effectiveness against maritime threats. As a minimum, improving current ASE software to encompass significant maritime threats is deemed prudent, with radar detection and countermeasure systems of particular importance.

The Fire Control Radar on the AH-64D is less effective in maritime environments due to a lack of "maritime mode" to decipher high seas (waves) from valid targets. ${ }^{73}$ The addition of a maritime mode and maritime threat library to effectively identify targets/threats would increase its effectiveness and reduce risk significantly. Also, the Army and Navy do not have fully compatible communication capabilities. There is sufficient commonality to enable short duration, ad hoc operations, but the interoperability of ultra high frequency, very high frequency, secure voice, identification, and friend or foe squawks to include cryptological requirements must be

\footnotetext{
${ }^{72}$ Henry C. Perry and Brian Hummel, 23.

${ }^{73}$ AH-64D Longbow Apache FCR Training Update (Washington, DC: Government Printing Office, 2006), 12.
} 
addressed prior to conducting operations. ${ }^{74}$ Investment to enhance the interoperability in communications systems would be prudent if the Army elects to establish a long term, standing shipboard capability.

\section{Force Generation}

Historically, Army aviation has been employed from ships in an ad hoc fashion. Units selected for shipboard employment had to conduct extensive training prior to embarking, which normally required several months to complete. ${ }^{75}$ While this approach has proven effective in the past, it does not provide for a responsive capability. One approach to realizing a standing capability is to utilize a 'dynamic' readiness model on the lines of the Army Forces Generation plan. This would require (at a minimum) three like-type formations to be committed to shipboard employment capability - one available, one in training, and one in reset. This approach will serve to proliferate shipboard experience/capability through a larger segment of the force, but also incur incrementally larger training and equipping demands than the static approach outlined below.

Another option is a 'static' readiness model, using a single unit - or set of units - to maintain readiness for shipboard employment at all times. This approach will tend to restrict shipboard experience to a very limited segment of the force, but incur lower training and equipping costs. Selecting the 'right' units to develop and maintain shipboard operating capability will require careful consideration of unit location, proximity to overwater training assets, training/support demands outside of shipboard employment, organizational design, and previous overwater experience/expertise.

\footnotetext{
74 JP 3-04, C-3.

${ }^{75}$ Henry C. Perry and Brian Hummel, 22.
} 
Army Aviation Shipboard Operations: A Scenario

The Army aviation shipboard operations recommended above would be employed as part of enabling the US Army to accomplish its current set of missions anywhere in the world, but especially in the PACOM AOR. Despite the Pacific being viewed as a maritime and air-centric theater, Army aviation forces will provide an increased amount of forces to the Combatant Commander should the need arise to meet the theater strategic objectives. As recent historical precedent has shown, a likely scenario that would require the implementation of Army aviation forces from naval ships is that of a catastrophic natural disaster in the region. Examples include humanitarian assistance efforts in support of Operation Tomodachi following the unprecedented earthquake, tsunami, and nuclear disaster that struck Japan in 2011 and the US military’s response to the massive flooding in Pakistan in 2010.

The year is now 2020, and this scenario begins with a satellite picking up a tropical storm in the Pacific Ocean. Weather experts are confident that this tropical storm will hit the Mindanao Islands of the Philippines in the next four days. Elsewhere around the PACOM AOR, the Korean Peninsula has been peaceful for the last five years as unification talks continue to progress. The Chinese have continued to stake claims to the disputed islands chains in the South China Sea and have increased aggressive and provocative actions in support of their claims. These actions have the countries of Vietnam and the Philippines on a heightened state of alert and they have requested the USN and USMC to support their efforts at protecting what they deem to be sovereign lands. In response, PACOM ordered the 15th MEU to conduct partnered operations ashore in those countries. The 13th MEU is in Australia participating in a large regional capacity building exercise and the 31st MEU just returned from an operational deployment and are in the build phase of the MEU cycle.

The PACOM commander, understanding that all the region's USMC aviation assets are being utilized in support of critical operations or unavailable, seeks a way to be prepared to 
provide humanitarian assistance to the Philippines if requested. Because the majority of the aircraft from the 15th MEU have disembarked and are supporting the ground forces ashore from inland airfields, PACOM orders a LHA, the USS America, to steam to Korea to embark a task force of Army aviation lift aircraft. Because of the increased focus on shipboard operations within Army aviation, the aviation task force from Korea was fully qualified to conduct overwater operations and deck landings on navy ships prior to notification for this tasking. Having a transit time of two and a half days each way and allowing one day for loading in Korea, the America is able to support humanitarian assistance operations two days after the storm hits the islands of Mindanao.

With a population of over 21 million people, the potential for casualties and displaced personnel is immense. After the storm makes landfall, the Philippine government assesses that there are over 400,000 displaced personnel and over 3,500 people who need MEDEVAC to safety. All the main roads leading to the affected area are flooded and the only way to get to the area is by helicopter. The Army aviation task force embarked on the America consists of $12 \mathrm{CH}-$ 47Fs, six UH-60Ms, and four HH-60Ms that will be utilized to conduct further aerial assessments, deliver supplies, and MEDEVAC injured personnel, all while based on and flying off of the USS America. Over the course of the 14-day mission, all requests for support were met, human suffering was alleviated, and the Army aviation task force returned to Korea. As this scenario describes, Army aviation, through its scalable and tailorable capabilities, expanded the PACOM commander's options and operational reach during humanitarian assistance operations.

\section{Conclusion}

Army aviation is a powerful, capable force multiplier with tremendous potential for supporting naval operations, and is capable of employing rotary-wing formations from Navy vessels in contingency operations anywhere in the Pacific AOR. As part of this employment, 
Army aviation’s core missions (attack, reconnaissance, security, air assault, air movement, and MEDEVAC) do not change, only the conditions under which they are executed do.

With the national strategy shift in focus to the Asia-Pacific region, it is likely that any operations by U.S. forces will contain significant littoral regions. Army aviation must have the ability to operate shore-to-ship or ship-to-shore from a carrier strike group, expeditionary strike group, or surface strike group. This provides the PACOM commander flexibility when deciding how to project combat power from a sea-based platform to execute missions throughout the full range of military operations.

In nearly every major conflict and operation since World War II, Army aviation has been assigned missions in the maritime environment, either basing off naval vessels for land attack or operating from ships for sustained overwater missions. With Operation Earnest Will in the Persian Gulf, Operation Uphold Democracy in Haiti, and Operation Ellamy in Libya as historical precedent, the concept of employing Army aviation helicopters in conjunction with the mobility of naval ships can be validated and shown to have implications for future operations. Recent worldwide deployments have shown that Army aviation has a versatile combination of technology, deployability, and personnel to accomplish missions that require operations in the maritime environment.

In order to understand how Army aviation can help an operational commander dominate an area of operations, it is essential to understand both the Joint force's and the Army's doctrinal principles for the employment of aviation assets in a maritime environment. Based on the review of both Joint and Army shipboard operations doctrine, it can be concluded that Army doctrine requires updating to reflect and incorporate the myriad of changes in the structure and execution of Joint operations. Much of the Army doctrine on shipboard operations is focused on the tactical level and provides little guidance to the operational commander on the implementation of the tactics described. Joint doctrine is more relevant based on the currency of its publication and it 
does more to inform the operational level commander on the integration and implementation of shipboard Army aviation assets in the maritime environment.

Through the use of ship-based force packages that can be scaled from team to battalion task force size and tailored with specific capabilities (attack, reconnaissance, security, air assault, air movement, and MEDEVAC), Army aviation can provide support to a wide range of joint force missions. These force packages have limitations and increased financial costs, but in the right circumstances, such a capability can be invaluable to the PACOM Commander - and well worth the investment. While shipboard employment will present a number of limitations and challenges, these can be mitigated with thorough training, disciplined operations, and proper risk management. By adapting its core missions to a maritime environment, Army aviation can meet the needs of an operational level commander in PACOM by conducting or supporting a broad spectrum of shipboard aviation operations.

The primary recommendation of this study is directly related to the research question, what should the operational role be for Army aviation in a maritime theater, specifically the USPACOM AOR? Army aviation in the USPACOM AOR should be employed as scalable and tailorable task forces operating from Navy vessels and platforms supporting the full range of military operations. Additionally, Army doctrine requires updating to reflect and incorporate the myriad of changes in joint operations since 1997. Much of the Army doctrine on shipboard operations is focused on the tactical level and provides little guidance to the operational commander on the implementation of the tactics described. Finally, there is a need for an increase in institutional training and establishing procedures in support of shipboard operations that would facilitate Army preparation for deck landing qualifications. 


\section{Bibliography}

101st Airborne Division (Air Assault) Gold Book. Washington, DC: Government Printing Office, 2010.

AH-64D Longbow Apache FCR Training Update. Washington, DC: Government Printing Office, 2006.

Air-Sea Battle: Service Collaboration to Address Anti-Access \& Area Denial Challenges. Washington, DC: Government Printing Office, 2013.

“Amphibious Ready Group and Marine Expeditionary Unit Overview.” Washington, DC: Government Printing Office, 2014.

BBC News. “Libya: UK Apache Helicopters Used in NATO Attacks.” June 4, 2011. Accessed September 10, 2014. http://www.bbc.co.uk/news/uk-13651736.

Brooks, Vincent K., and Charlie H. Kim. "U.S. Army Pacific Makes Major Moves to Face Regional Challenges.” Army Magazine (April 2014): 30-36.

Carter, Jimmy. "The State of the Union Address Delivered Before a Joint Session of the Congress.” The American Presidency Project, January 23 1980. Accessed 15 September, 2014. http://www.presidency.ucsb.edu/ws/?pid=33079.

Crist, David B. “Joint Special Operations in Support of Earnest Will.” Joint Force Quarterly Autumn-Winter (2001-2002): 15-22.

Farrington, Christopher. “USS Freedom Departs on Maiden Deployment.” US Navy, 1 March 2013. Accessed June 20, 2014. http://www.navy.mil/submit/display.asp?story_id=72459.

Field Manual 1-100, Army Aviation Operations. Washington, DC: Government Printing Office, 1997.

Field Manual 1-564, Shipboard Operations. Washington, DC: Government Printing Office, 1997.

Field Manual 3-04.111, Aviation Brigades. Washington, DC: Government Printing Office, 2007.

Field Manual 3-04.126, Attack Reconnaissance Helicopter Operations. Washington, DC: Government Printing Office, 2007.

Field Manual 3-104.113, Utility and Cargo Helicopter Operations. Washington, DC: Government Printing Office, 2007.

Gray III, Sidney J., and Charles W. Weigandt. "The 160th SOAR: 20 Years of Army SpecialOperations Aviation." Special Warfare 14, no. 3 (Summer, 2001): 6-11.

“HMS Bangor En Route to Libya.” June 7, 2011. Accessed September 10, 2014. http://www.mod.uk/DefenceInternet/DefenceNews/MilitaryOperations/HmsBangorEnRo uteToLibya.htm. 
Joint Publications 1-02, Department of Defense Dictionary of Military and Associated Terms. Washington, DC: Government Printing Office, 2010.

Joint Publication 3-04, Joint Shipboard Helicopter and Tiltrotor Aircraft Operations. Washington, DC: Government Printing Office, 2012.

Kretchik, Walter E., Robert F. Baumann, and John T. Fishel. Invasion, Intervention, "Intervasion": A Concise History of the U.S. Army in Operation Uphold Democracy. Fort Leavenworth, Kansas: U.S. Army Command and General Staff College Press, 1998.

Lambert, Geoffrey C., and Mark M. Huber. "Joint Shipboard Helicopter Operations." Joint Forces Quarterly Winter 2000-01 (2001): 83-88.

“Lessons Offered From the Libya Air Campaign”. Royal Aeronautical Society (July 2012): 12.

Marine Corps Doctrinal Publication 1-0, Marine Corps Operations. Washington, DC: Government Printing Office, 2011.

Marine Corps Reference Publication 3-25J, Air Operations in Maritime Surface Warfare. Washington, DC: Government Printing Office, 2014.

Marine Corps Reference Publication 5-12D, Organization of Marine Corps Forces. Washington, DC: Government Printing Office, 1998.

McGrady, E.D., and Robert E. Sullivan. Operation Uphold Democracy: Observations on Joint Assault Operations From a CV. Alexandria, VA: Center for Naval Analysis, 1996.

MCRP 3-25J/NTTP 3-20.8/AFTTP 3-2.74, Air Operations in Maritime Surface Warfare. Washington, DC: Government Printing Office, 2014.

Miles, Donna. “Obama Announces Expanded U.S. Military Presence in Australia”. U.S. Department of Defense. November 16, 2011. Accessed September 15, 2014. http://www.defense.gov/news/newsarticle.aspx?id=66098.

. "Rotational Force in Australia Paves Way for Big Growth in 2014”. U.S. Department of Defense. September 24, 2013. Accessed September 15, 2014. http://www.defense.gov/news/newsarticle.aspx?id=120844.

Partin, John W. Special Operations Forces in Operation Earnest Will/Prime Chance I. Hurlburt Air Force Base, Florida: US Special Operations Command, History and Research Office, 1998.

Partnering in the Asia-Pacific Theater: The U.S. Army, Pacific Theater Engagement Strategy White Paper. Washington, DC: Government Printing Office, 2012.

Perry, Henry C., and Brian Hummel. "Preparing for Maritime Contingency Operations." Aviation Digest October-December (2013): 22-25.

Sustaining U.S. Global Leadership: Priorities for 21st Century Defense. Washington, DC: Government Printing Office, 2012. 
Taylor, Mark. “MUM-T: Training is the Key Ingredient.” Aviation Digest (July-Sep 2014): 5-6.

UK Ministry of Defence. “Good Progress Seen in Libya Operations.” June 24, 2011. Accessed September 10, 2014. http://www.mod.uk/DefenceInternet/DefenceNews/MilitaryOperations/GoodProgressSee nInLibyaOperations.htm.

. "RAF Destroys Nine of Gaddafi's Underground Storage Bunkers in Libya.” June 13, 2011. Accessed September 10, 2014. http://www.mod.uk/DefenceInternet/DefenceNews/MilitaryOperations/RafDestroysNine OfGaddafisUndergroundStorageBunkersInLibya.htm.

United Nations. “UN Security Council Resolution 1973.” March 17, 2011. Accessed September 10, 2014. http://www.un.org/press/en/2011/sc10200.doc.htm.

US Department of Defense. "Remarks by Secretary Gates at the Shangri-La Dialogue, International Institute for Strategic Studies, Singapore.” June 3, 2011. Accessed June 15, 2014. http://www.defense.gov/transcripts/transcript.aspx?transcriptid=4831.

US Navy Program Guide 2014. Washington, DC: Government Printing Office, 2014.

US Navy. “Fact File: Amphibious Assault Ships.” Accessed 12 August 2014. http://www.navy.mil/navydata/fact_display.asp?cid=4200\&ct=4\&tid=400.

. "Pacific Fleet Ships by Class.” Accessed 12 August 2014. http://www.public.navy.mil/surfor/Pages/USNavyPacificFleetShipsbyClass.aspx.

. “SURFPAC's Amphibious Assault Ship (LHD/LHA) Info Page.” Accessed 18 November 2014. http://www.public.navy.mil/surfor/Pages/AmphibiousAssualtShip.aspx.

The White House. "Remarks by President Obama to the Australian Parliament.” November 17, 2011. Accessed June 15, 2014, http://www.whitehouse.gov/the-pressoffice/2011/11/17/remarks-president-obama-australian-parliament. 